\title{
A constant Chinese Loess Plateau dust source since the late Miocene
}

\author{
Anna Bird ${ }^{\text {a, b, * }}$, Ian Millar ${ }^{\mathrm{c}}$, Tanja Rodenburg ${ }^{\mathrm{b}}$, Thomas Stevens ${ }^{\mathrm{b}, \mathrm{d}}$, Martin Rittner ${ }^{\mathrm{e}}$, \\ Pieter Vermeesch ${ }^{\mathrm{e}}$, Huayu $\mathrm{Lu}^{\mathrm{f}}$ \\ a School of Environment Sciences, University of Hull, Hull, HU6 7RX, UK \\ b Department of Geography, Royal Holloway University of London, Egham, Surrey, TW20 OEX, UK \\ ${ }^{\mathrm{c}}$ NERC Isotope Geosciences Laboratory, British Geological Survey, Keyworth, UK \\ d Department of Earth Sciences, Uppsala University, Geocentrum, Villav. 16, 752 36, Uppsala, Sweden \\ e Department of Earth Sciences, University College London, London, WC1E 6BT, UK \\ ${ }^{\mathrm{f}}$ School of Geographic and Oceanographic Sciences, Nanjing University, Nanjing, 210093, China
}

\section{A R T I C L E I N F O}

\section{Article history:}

Received 22 May 2019

Received in revised form

16 October 2019

Accepted 29 October 2019

Available online $\mathrm{xxx}$

\section{Keywords:}

Quaternary

Neogene

Palaeoclimate

China

Loess

Radiogenic isotopes

\begin{abstract}
A B S T R A C T
The Pliocene-Pleistocene boundary marks a major change in global climate and East Asian monsoon dynamic. However, the role of the global atmospheric dust-cycle over this time is unclear; in particular the degree to which changes in the dust cycle influenced climate change, were driven by climate change, and how these processes interacted. Chinese loess records past dust-cycle history and the influences of aridification and monsoon circulation over the last 40 Ma. Previous work on the Chinese Loess Plateau argue over whether changes in dust source occur at the Pliocene-Pleistocene boundary, or at $1.2 \mathrm{Ma}$, despite these intervals marking major shifts in monsoon dynamics. We present $\mathrm{Sr}$, $\mathrm{Nd}$ and $\mathrm{Hf}$ isotope data from multiple sites and show that dust source largely remains unchanged across these boundaries. Shifts in geochemistry are due to changes in grain-size and weathering. While the transport pathway (river, deserts, direct aeolian) is unclear, these tracer isotopes show that dust was dominantly sourced from the Northern Tibetan Plateau, with some input from the local bedrock. This shows that a major established and constant dust source on the Tibetan Plateau has been active and unchanged since late Miocene, despite dramatically changing climate conditions. Changes in loess accumulation are a function of climate change in Tibetan Plateau source regions rather than effects from increased aridification over the Pliocene-Pleistocene boundary.
\end{abstract}

๑ 2019 The Authors. Published by Elsevier Ltd. This is an open access article under the CC BY license (http://creativecommons.org/licenses/by/4.0/).

\section{Introduction}

Atmospheric dust dynamics play a central but poorly understood role in climate change, with past source activity identified as a key focus for future research (Merkel et al., 2014). Despite the significance for understanding Cenozoic global climate change, little is known about the evolution of the dust cycle during the major global climate reorganizations of the Pliocene and Quaternary. Wind-blown dust deposits on the Chinese Loess Plateau are recognized as one of the most valuable terrestrial climate archives available, spanning at least the last $25 \mathrm{Ma}$, making the sequence the longest and most continuous dust archive on the planet (Guo et al., 2002; Lu et al., 2010; Licht et al., 2016). The Loess Plateau is located

\footnotetext{
* Corresponding author. School of Environment Sciences, University of Hull, Hull, HU6 7RX, UK.

E-mail address: a.bird@hull.ac.uk (A. Bird).
}

in north-central China, and contains a near unique, detailed record of dust dynamics across the Pliocene and Quaternary. At 2.5 Ma a marked change is seen from Pliocene 'Red Clay' deposits to Quaternary soils and loess (Ding et al., 2000; Porter et al., 2001). The deposition and diagenesis of these sediments is intimately tied to climate, and the sources of Loess Plateau dust have been hypothesized to be a major controlling factor in glacial-interglacial climate changes in the Quaternary (Watson et al., 2000). What remains unclear is whether the shifts in climate and the nature of windblown dust across the Neogene and Quaternary are tied to shifts in dust source. This represents a major gap in understanding of how dust influences and responds to global and regional climate change.

Investigations into loess sources have used a variety of techniques including whole rock $\mathrm{Nd}$ and $\mathrm{Sr}$ isotopes, major and trace element chemistry, magnetic susceptibility, zircon $\mathrm{U}-\mathrm{Pb}$, and heavy mineral analysis. Each of these methods provides slightly different information about dust sources. For example, using whole rock $\mathrm{Nd}$ and $\mathrm{Sr}$ isotopes or major/trace elements to establish 
provenance has the advantage of allowing investigation of all grainsizes and the disadvantage of averaging out potentially distinct sediment source signatures (e.g. Gallet et al., 1996; Ding et al., 2002). To tackle this issue, recent studies have used zircon $\mathrm{U}-\mathrm{Pb}$ (Stevens and Lu, 2010; Pullen et al., 2011; Xiao et al., 2012; Stevens et al., 2013; Che and Li, 2013; Bird et al., 2015; Nie et al., 2015; Licht et al., 2016; Zhang et al., 2018, 2016). Most of these single-grain studies suggest that the northern Tibetan Plateau is the dominant source of the loess with input from the North China Craton (Che and Li, 2013; Bird et al., 2015; Nie et al., 2015; Zhang et al., 2018, 2016). A problem with this approach is that zircons are predominantly derived from granitoids, inevitably biasing the dataset towards these sources. Furthermore, only the coarser (often $>40 \mu \mathrm{m}$ ) zircons are analysed due to analytical limitations and this can introduce a size bias to data (e.g. Bird et al., 2015). Finally, as zircon is an extremely robust mineral it can survive many cycles of sediment recycling and may not always provide insight into the most recent sediment transport phase.

Previous single grain and whole rock studies are unclear about the nature of dust source change through time. This is both true for whether variation in sources can be related to glacial/interglacial cycles (Jahn et al., 2001; Sun et al., 2008; Pullen et al., 2011) and for longer term source shifts. Changes in loess source have been reported at 1.2 Ma (Sun, 2005; Chen and Li, 2013), and 2.5 Ma (Chen et al., 2007; Sun and Zhu, 2010; Nie et al., 2014). These source changes are seen in ${ }^{87} \mathrm{Sr} /{ }^{86} \mathrm{Sr}$ data, in some cases in ${ }^{143} \mathrm{Nd} /{ }^{144} \mathrm{Nd}$ (e.g. Sun, 2005; Chen and Li, 2013) and in one case Pb isotopes (Sun and Zhu, 2010). In addition to these geochemical datasets the sequence on the Loess Plateau changes from loess/soil to Red Clay around the Pliocene-Pleistocene boundary at c. $2.5 \mathrm{Ma}$ (e.g. Sun, 2005). These studies suggest that there is a change in source or type of material delivered to the Plateau at this time. Other work suggests that the source was constant from 7 to $1.2 \mathrm{Ma}$ when there was a decrease in the amount of material transported from the Qilian Mountains and a shift in palaeosol frequency (Chen and $\mathrm{Li}$, 2013). However these potential variations in source are not seen in other studies using ${ }^{143} \mathrm{Nd} /{ }^{144} \mathrm{Nd}$ (Gallet et al., 1996; Wang et al., 2007), ${ }^{176} \mathrm{Hf} /{ }^{177} \mathrm{Hf}$ (Chauvel et al., 2014) or some single grain zircon U-Pb studies (Bird et al., 2015). Thus, at present there is a major disagreement about a fundamental aspect of Cenozoic dust and climate evolution. Here we present new data from 134 samples (for full sample details see Supplementary Data Table 1) obtained from the Chinese Loess Plateau and potential source areas (see Fig. 1), along with published data, which demonstrate that dust sources show no systematic change from Miocene to Holocene times. This demonstrates that the sources of the majority of the Loess Plateau sediments show no systematic change, although proxies for individual components (e.g. zircon $\mathrm{U}-\mathrm{Pb}$ ) of loess do show variability, though there is disagreement on how systematic this variability is.

\section{Methods}

$\mathrm{Nd}, \mathrm{Sr}$ and $\mathrm{Hf}$ analyses were undertaken at NIGL, Keyworth, UK on a single dissolution. The whole rock powders were leached using $5 \mathrm{ml}$ of $10 \%$ acetic acid for $30 \mathrm{~min}$ at $60^{\circ} \mathrm{C}$ to remove carbonate then washed in Milli-Q water and dried. Mixed ${ }^{149} \mathrm{Sm}^{-}{ }^{150} \mathrm{Nd},{ }^{176} \mathrm{Lu}-{ }^{180} \mathrm{Hf}$ and single ${ }^{84} \mathrm{Sr}$ and ${ }^{87} \mathrm{Rb}$ isotope tracers were then weighed and added and the samples were digested by standard $\mathrm{HF} / \mathrm{HNO}_{3}$ dissolution. Early samples were not mixed with the ${ }^{176} \mathrm{Lu}-{ }^{180} \mathrm{Hf}$ spike; these samples have no $\mathrm{Hf}$ concentration data. $\mathrm{Hf}, \mathrm{Nd}$ and $\mathrm{Sr}$ were separated using standard ion-exchange procedures.

$\mathrm{Nd}$ and $\mathrm{Sr}$ were analysed in a Thermo Scientific Triton mass spectrometer in multi-dynamic mode. Nd data were normalized to ${ }^{146} \mathrm{Nd} /{ }^{144} \mathrm{Nd}=0.7219$ and $\mathrm{Sr}$ data were normalized to
${ }^{86} \mathrm{Sr} /{ }^{88} \mathrm{Sr}=0.1194$. Across the time of analysis, 57 analyses of the JND-i standard (Tanaka et al., 2000) gave a mean value of $0.512102 \pm 0.000009$ (10.4 ppm, 1 -sigma). All ${ }^{143} \mathrm{Nd} /{ }^{144} \mathrm{Nd}$ values were normalized to a preferred value of 0.512115 for JND-i. 17 analyses of standard La Jolla (Lugmair and Carlson, 1978) gave $0.511860 \pm 0.000008$ (12.8 ppm, 1-sigma). 176 analyses of NBS987 across the time of analysis gave a value of $0.710251 \pm 0.000007$ (9 ppm, 1-sigma). NBS987 standards analysed with the samples gave a value of $0.710251 \pm 0.000007(7.8 \mathrm{ppm}, 1$-sigma, $\mathrm{n}=14$ ) This is within analytical uncertainty of the preferred value for this, so no secondary correction of the data was required.

Hf was analysed on a Thermo-Electron Neptune mass spectrometer using a Cetac Aridus II desolvating nebuliser. 0.006 1/min of nitrogen were introduced via the nebuliser in addition to $\mathrm{Ar}$ in order to minimize oxide formation. The instrument was operated in static multicollection mode, with cups set to monitor ${ }^{172} \mathrm{Yb},{ }^{173} \mathrm{Yb}$, ${ }^{175} \mathrm{Lu},{ }^{176} \mathrm{Lu}+\mathrm{Hf}+\mathrm{Yb},{ }^{177} \mathrm{Hf},{ }^{178} \mathrm{Hf},{ }^{179} \mathrm{Hf}$ and ${ }^{180} \mathrm{Hf} .1 \%$ dilutions of each sample were tested prior to analysis, and samples diluted to $\mathrm{c}$. $20 \mathrm{ppb}$. Data are reported relative to ${ }^{179} \mathrm{Hf} /{ }^{177} \mathrm{Hf}=0.7325$. The $\mathrm{Hf}$ standard solution JMC475 was analysed during each analytical session and sample ${ }^{176} \mathrm{Hf} /{ }^{177} \mathrm{Hf}$ ratios are reported relative to a value of 0.282160 for this standard. Across the 26-month period of analysis, 189 analyses of JMC475 gave a mean ${ }^{176} \mathrm{Hf} /{ }^{177} \mathrm{Hf}$ value of $0.282150 \pm 0.000009$ (23.1 ppm, 1-sigma). Typical external precision for a single day's analysis was in the range between 13 and $22 \mathrm{ppm}$. Detailed results can be found in the Supplementary File.

Mixing hyperbolae are calculated using standard mixing equations (Faure, 2001) with average upper continental crust and bulk crust values (Rudnick and Gao, 2003) and average mantle values (Mcdonough and Sun, 1995). ${ }^{143} \mathrm{Nd} /{ }^{144} \mathrm{Nd}$ and ${ }^{176} \mathrm{Hf} /{ }^{177} \mathrm{Hf}$ ratios in this study are reported as $\varepsilon_{\mathrm{Nd}}$ and $\varepsilon_{\mathrm{Hf}}$, using the present-day chondritic uniform reservoir (CHUR) values of 0.512630 and 0.282785, respectively (Bouvier et al., 2008).

\section{Results and discussion}

\subsection{Sr, Nd and Hf variations in the Chinese Loess Plateau}

Down-section variations in $\mathrm{Sr}$, Nd and Hf-isotope data for our Chinese Loess whole rock samples are shown in Fig. 2, together with published data (Gallet et al., 1996; Wang et al., 2007; Chen and Li, 2013; Chauvel et al., 2014; Zhang et al., 2015). Only published data that have been analysed using a very similar method as the samples here have been included to limit effects caused by different leaching methods.

Fig. 2a) and b) show ${ }^{143} \mathrm{Nd} /{ }^{144} \mathrm{Nd}$ plotted against the age of sediment. There is a range in the ${ }^{143} \mathrm{Nd} /{ }^{144} \mathrm{Nd}$ values obtained from within the same units, especially from material younger than $1 \mathrm{Ma}$. This is probably partly due to a sampling bias in that more studies have analysed loess and soil units younger than $1 \mathrm{Ma}$. The study by Zhang et al. (2015) is the only data here that may show a systematic decrease in ${ }^{143} \mathrm{Nd} /{ }^{144} \mathrm{Nd}$ down-section until $\sim 2.6 \mathrm{Ma}$ where the study stops. None of the other studies show any convincing systematic trend, nor does the data within this study. ${ }^{176} \mathrm{Hf} /{ }^{177} \mathrm{Hf}$ (Fig. 2 c and d) shows a similar lack of any systematic trend down section, although this dataset suffers from the opposite problem when compared to the $\mathrm{Nd}$ isotopic data in that there is much less data. ${ }^{87} \mathrm{Sr} /{ }^{86} \mathrm{Sr}$ shows an increase until 4 Ma where it plateaus and shows a slight decrease at $6 \mathrm{Ma}$ (Fig. 2e and f). None of the isotopic systems show an abrupt change at either 1.2 or $2.5 \mathrm{Ma}$.

${ }^{87} \mathrm{Sr} /{ }^{86} \mathrm{Sr}$ is the only isotopic system to show a systematic trend related to the age of the sediment, and there does not seem to be any correlation between ${ }^{87} \mathrm{Sr} /{ }^{86} \mathrm{Sr}$ and the other two isotopic systems, this is shown in Fig. 3 which is a PCA for all three isotopic systems. This clearly demonstrates that there is a separate control 

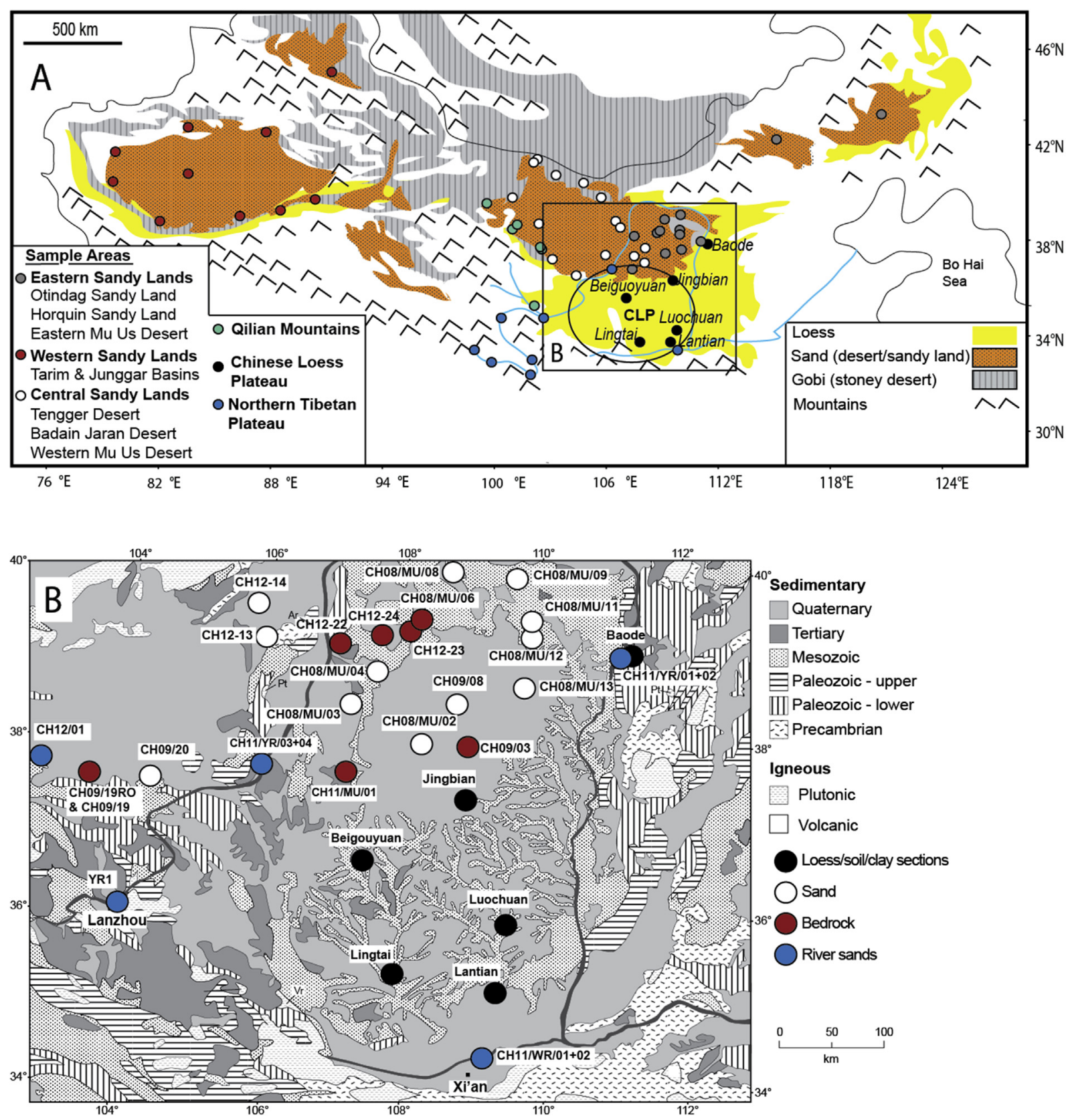

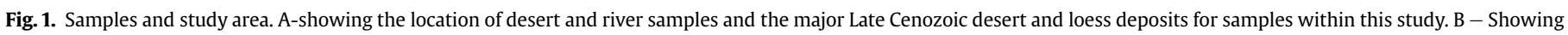

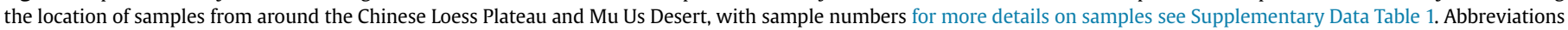
are CLP - Chinese Loess Plateau; SR - Huangshui River; UB - Ulan Buh Sandy Land; WR - Weihe River. (Stevens et al., 2013; Bird et al., 2015).

on ${ }^{87} \mathrm{Sr} /{ }^{86} \mathrm{Sr}$ when compared to ${ }^{176} \mathrm{Hf} /{ }^{177} \mathrm{Hf}$ and ${ }^{143} \mathrm{Nd} /{ }^{144} \mathrm{Nd}$.

As ${ }^{87} \mathrm{Sr} /{ }^{86} \mathrm{Sr}$ is the only isotopic system showing any systematic trend it is worth exploring what else, apart from provenance change can affect this system. ${ }^{87} \mathrm{Sr} /{ }^{86} \mathrm{Sr}$ can be affected by the addition of authigenic precipitates (such as carbonates). Our samples were leached in acetic acid in order to eliminate any such effect. ${ }^{87} \mathrm{Sr} /{ }^{86} \mathrm{Sr}$ can also be affected by chemical weathering or enrichment of minerals rich in radiogenic ${ }^{87} \mathrm{Sr}$ in fine grain-size fractions. The highest values of ${ }^{87} \mathrm{Sr} /{ }^{86} \mathrm{Sr}$ in our dataset are shown by the Red Clay, deposited prior to $2.5 \mathrm{Ma}$. Chemical weathering influences the ${ }^{87} \mathrm{Sr} /{ }^{86} \mathrm{Sr}$ signal as $\mathrm{Sr}$ is hosted within minerals that are readily weathered, for example, feldspar (Blum et al., 1993; White et al., 1999) and easily enters solution during weathering, so is readily removed from the original sediment (Blum and Erel,
1997). This suggests that in wet/humid climates, where there is greater chemical weathering, the dissolution of feldspar leads to $\mathrm{Sr}$ loss resulting in concentration of relatively high $\mathrm{Rb} / \mathrm{Sr}$, high ${ }^{87} \mathrm{Sr} /{ }^{86} \mathrm{Sr}$ minerals. This weathering effect could also explain a change in $\mathrm{Pb}$ isotope signatures at 2.56 Ma (Sun and Zhu, 2010), which might result from dissolution of $\mathrm{Pb}$-rich minerals like apatite and allanite (Erel et al., 2004), rather than a change in source. The impact of chemical weathering on sediment composition is supported by variations in $\mathrm{Zr} / \mathrm{Rb}$ ratios (Chen et al., 2006). It is also supported by evidence of shifts in the heavy mineral composition to more stable, weathering-resistant species with increasing depth in loess sections. This change has been interpreted to be due to these older units having been subjected to more humid conditions, under which less resilient minerals have undergone preferential 

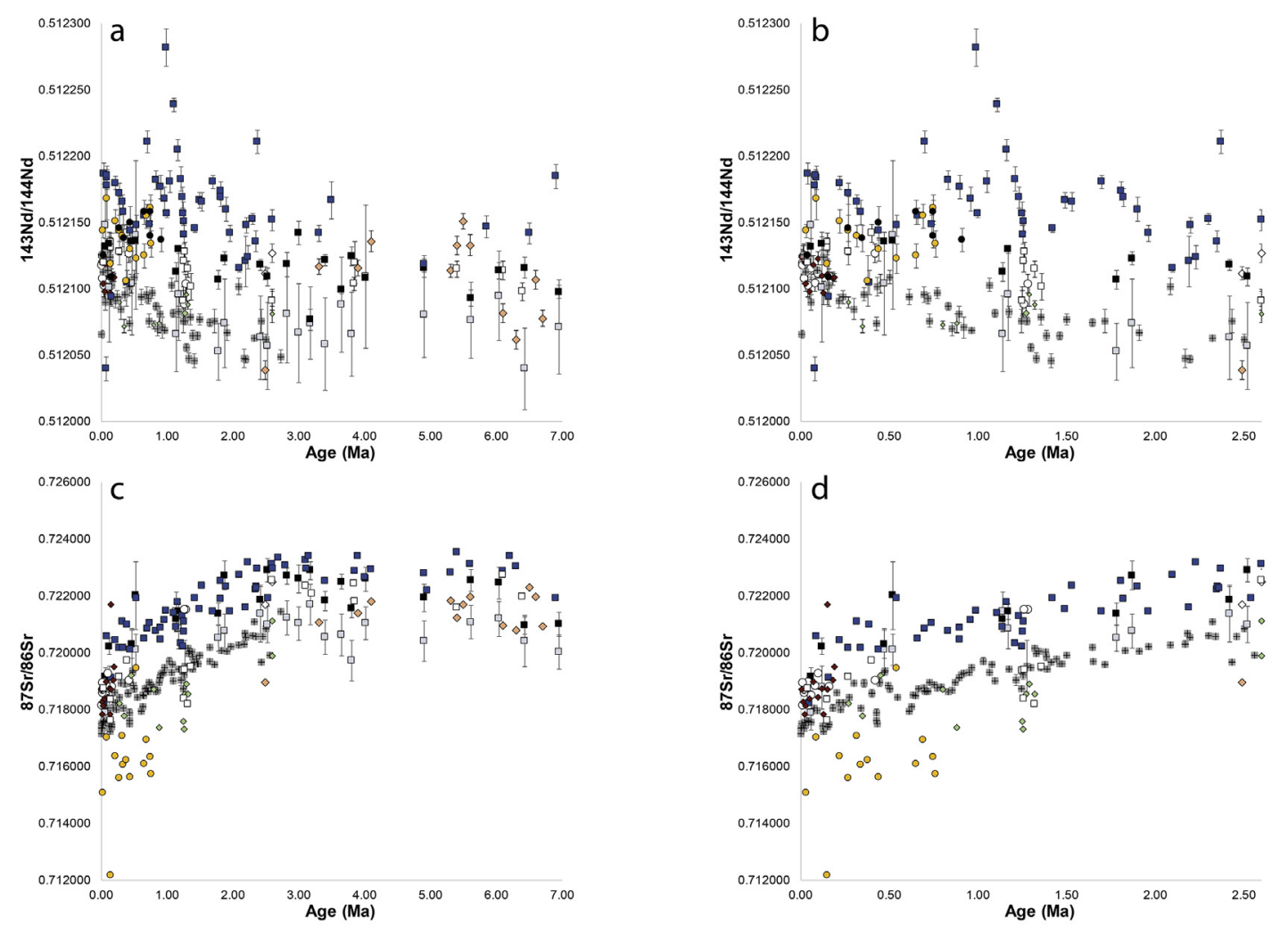

This Study

$\diamond \quad$ Lantian
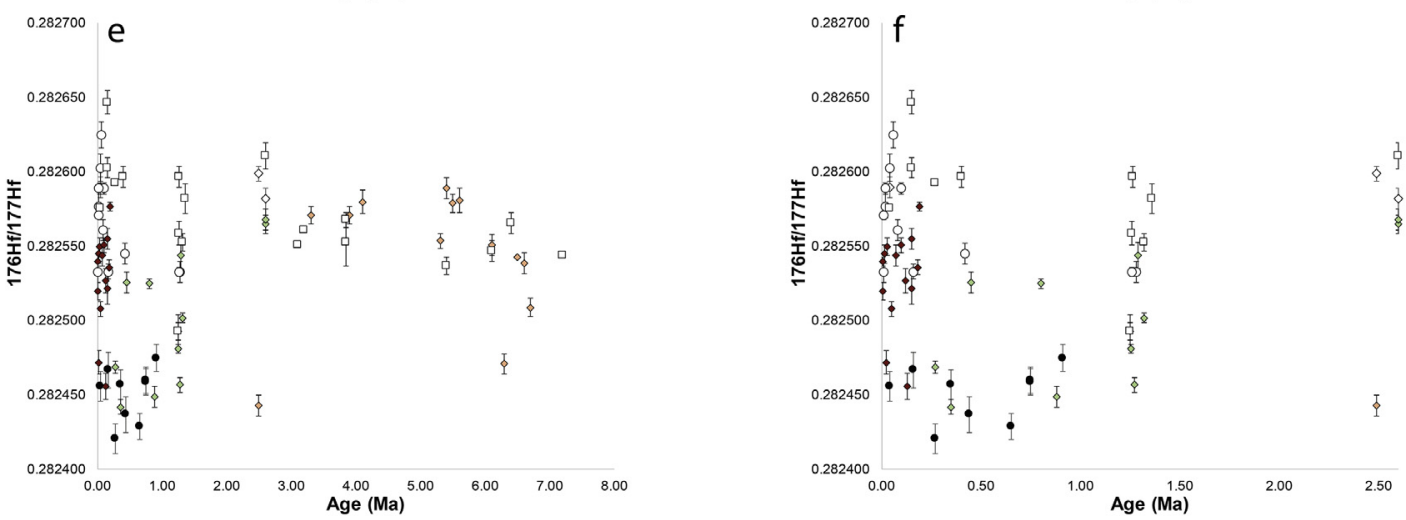

Luochuan

$\diamond \quad$ Baode

$\diamond \quad$ Jingbian

- Beigouyuan

$\square \quad$ Lingtai

Published Studies

- Chauvel et al 2015 Luochuan

\# Zhang et al 2015 Xifeng

․ Chen and Li $201328-45$ um Lingtai

- Chen and Li 2013 Bulk Lingtai

Wang et al 2007 Lingtai

- Gallet et al 1996 Luochuan

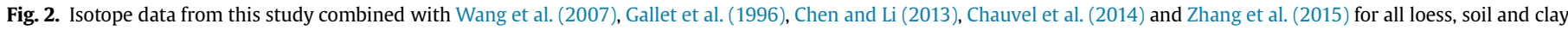

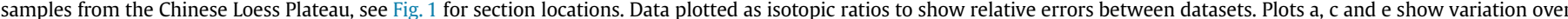

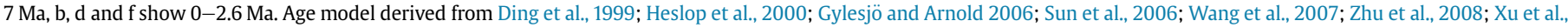
2009; Zhang et al., 2015.

dissolution (Bird et al., 2015; Nie, 2016; Peng et al., 2016).

Changes in ${ }^{87} \mathrm{Sr} /{ }^{86} \mathrm{Sr}$ can also be driven by grain-size, where finer grain-sizes will have higher ${ }^{87} \mathrm{Sr} /{ }^{86} \mathrm{Sr}$. At the Red Clay/loess boundary there is a change in grain-size from the finer grained Red Clay to coarser loess/soil units (Ding et al. 1998,1999; Lu et al., 2010; and Yang and Ding, 2010). However, both grain-sizes analysed by Chen and $\mathrm{Li}$ (2013) show an increasing ${ }^{87} \mathrm{Sr} /{ }^{86} \mathrm{Sr}$ with increasing age demonstrating grain-size is not the only control on ${ }^{87} \mathrm{Sr} /{ }^{86} \mathrm{Sr}$.

Rare earth elements and high field strength elements are relatively immobile during weathering; hence ${ }^{143} \mathrm{Nd} /{ }^{144} \mathrm{Nd}$ and ${ }^{176} \mathrm{Hf} /{ }^{177} \mathrm{Hf}$ appear to retain the character of the source material (Jung et al., 2004). These isotope systems do not systematically change at $1.2 \mathrm{Ma}$ or across the Pliocene-Pleistocene boundary (Fig. 2).

$\mathrm{Sr}$, Nd and Hf isotope data, show no evidence for major provenance changes at 2.5 or $1.2 \mathrm{Ma}$. A change in provenance signal cannot therefore be used to explain the different characteristics of the loess/soil and the Red Clay units (Figs. 2 and 3). The results here suggest that the change from Red Clay to loess/soil was likely to be driven by a change to a less humid climate and/or higher dust deposition rates on the CLP over the Plio-Pleistocene boundary. The constancy of dust source (at least finer grained dust) implies that there were no major changes in the origin and composition of atmospheric mineral dust over this part of Asia across a major climatic boundary. However, higher dust accumulation rates at the end of the Pliocene and into the Quaternary (Sun et al., 2011) suggest that the volume of dust material produced still increased dramatically. Combined, this implies that the volume of material produced from existing sources became greatly enhanced at the onset of the Quaternary, potentially due to a more arid climate or the integration of the Yellow River system, rather than there being additional supply from major new dust sources. Given that the 


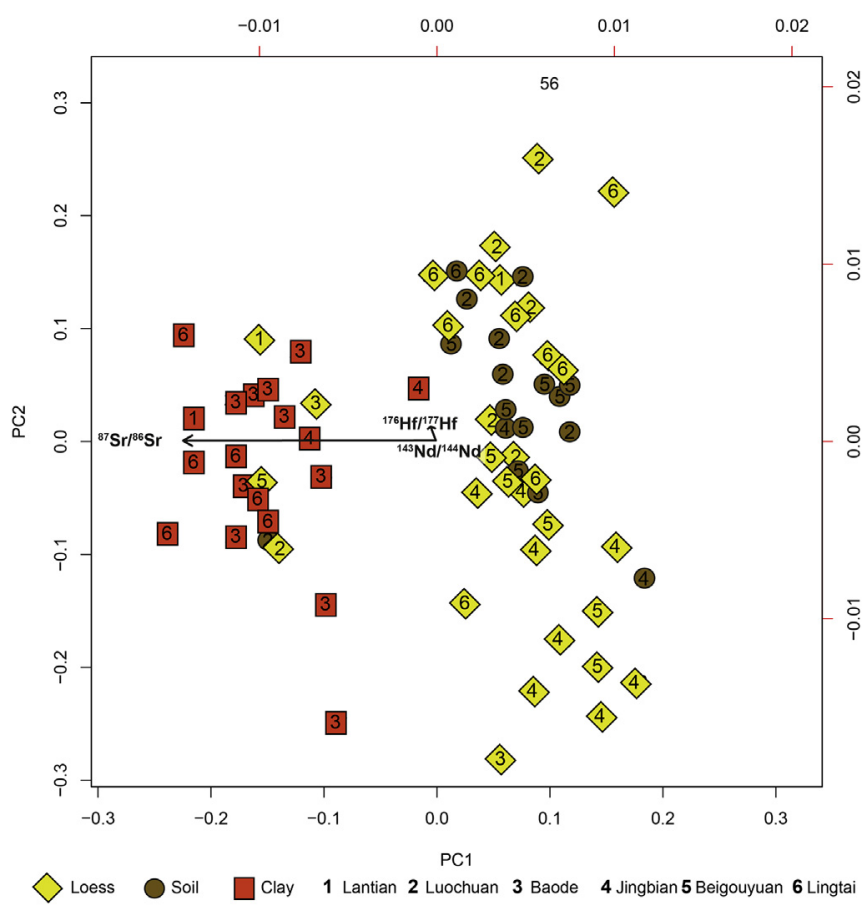

Fig. 3. PCA plot for the isotopic data from the samples within this study.

grain size of dust sediments greatly increases at this boundary, this implies a great strengthening of dust transporting winds from these constant source areas, or also further supports the idea that a new sediment transport route occurred at the time. The Yellow River is the prime candidate for such a transport route, facilitating the transportation of coarser material from the NTP to close to the CLP where the material can then be transported through aeolian processes onto the CLP (Nie et al., 2015). However, the timing of formation of the upper Yellow River is controversial and it is also possible some reworking of coarse grained western CLP material may have also occurred (Kapp et al., 2015).

\subsection{Loess source regions}

Critics of bulk sediment analysis suggest it likely averages source information from the potentially multiple sediment sources to loess, thus making it difficult to identify the individual source signals. The benefit of using this method is that it considers all grain sized fractions and likely reflects signatures in the dominant source areas, and is a strong tool when used alongside with other provenance methods. Here we propose that the sensitivity of bulk sediment analyses to source differences can be tested through comparison of results to a study that identifies unambiguous sediment source differences using single-grain analyses.

Stevens et al. (2010, 2013) undertook provenance analysis of sediments from the Mu Us desert (Fig. 1) using zircon $\mathrm{U}-\mathrm{Pb}$ and heavy mineral analysis, and showed that a clear difference in sediment source exists between the western and eastern parts of the desert. In order to test if bulk sediment isotopic analyses could detect this difference, a number of samples studied by Stevens et al. (2013) were selected for analysis. These included samples from the Mu Us Desert, the Yellow River at Zhongning, and the loess L1 (last glacial stage) from Beiguoyuan (sampled at the same depth in both studies).

Samples from the eastern Mu Us Desert have $\varepsilon_{\mathrm{Nd}}$ of c. -19 and $\varepsilon_{\mathrm{Hf}}$ of -21 whereas samples from the western part of the desert have $\varepsilon_{\mathrm{Nd}}$ of c. -12 and $\varepsilon_{\mathrm{Hf}}$ of -11 (Fig. 4). Notably, the samples from the western Mu Us desert have a similar signature to samples from the Yellow River, and loess from Beiguoyuan. This distinction between eastern and western Mu Us Desert signals is consistent with the conclusions of Stevens et al. (2013) using single grain methods, showing that bulk sediment isotopes will provide useful information on sediment source.

The data reported here and the published work (Gallet et al., 1996; Chen et al., 2007; Wang et al., 2007; Sun, 2005; Li et al., 2011; Che and Li, 2013; Chauvel et al., 2014; Zhang et al., 2012, 2015) cover a large geographical area (Fig. 1). So to help with interpretation the data were split into regional source areas as suggested by Licht et al. (2016); in addition, the Mu Us Desert has been split into eastern and western regions based on Stevens et al. (2013), Zhang et al. (2016) and the data in Fig. 4. Since the isotopic bulk sediment data include the very fine-grained fraction, the Tarim and Junggar basins were also added as potential regional source areas. The regional source areas are as follows:

1. Central Sand Lands - including the Badain Jaran, Tengger, western Mu Us and Ulan Buh deserts, and bedrock samples.

2. Eastern Sandy Lands - including Otindag and Horquin sandy lands and the eastern Mu Us desert, underlying bedrock and middle reach Yellow River samples (Nie et al., 2015).

3. Western Mu Us Desert - western China Basins (Tarim and Junggar basins).

4. Northern Tibetan Plateau - Upper Yellow River samples using the definition of upper river from Nie et al. (2015).

5. Qilian Mountains - samples from alluvial fans of rivers derived from the Qilian Mountains.

$\mathrm{Nd}$, Hf or $\mathrm{Sr}$ concentrations are not often available with published isotopic data. As such, calculating potential end members of the source areas which contribute most to the Chinese Loess Plateau is impossible. Despite this several key observations and interpretations can be made from the data. The loess, soil and Red Clay plot in a well-defined area that is overlapped most significantly by samples from the Northern Tibetan Plateau and the Qilian Mountains with some overlap from samples from the Central and Western Sandy Lands. The Eastern Sandy Lands plot reasonably well away from the CLP samples. This is seen more clearly on Fig. 5b and Fig. 5c, indicating the dominance of more westerly or northwesterly sources.

All three isotopic systems show that the loess, soil and clay data overlap with the samples from the Yellow River/Tibetan Plateau suggesting a Northern Tibetan Plateau source (Fig. 5a, b \& c). This is supported by recent hypotheses concerning sediment routing from the NTP via the Yellow River and other rivers to the CLP using single grain analysis (Stevens et al., 2013; Nie et al., 2015, 2014; Bird et al., 2015; Licht et al., 2016). There is some overlap with samples from CSL, QM and WSL with the samples from the CLP that suggest that sediment from these potential source areas are also sourced from the NTP (e.g. Chen et al., 2007; Rittner et al., 2016).

Previous work suggests that due to a weak NW-SE grain-size gradient in the Red Clay, in contrast to that shown in the Quaternary loess, the East Asian winter monsoon played a relatively smaller role in Red Clay deposition than in Quaternary loess deposition (Wen, 2005; Han et al., 2007). This implies that high altitude westerly winds were the main transport mechanism for dust at this time (Ding et al., 1998, 1999; Gylesjö and Arnold, 2006) and perhaps implies a change in source. A recent zircon $\mathrm{U}-\mathrm{Pb}$ study also suggests a subtle source change across this boundary (Nie et al., 2015). However, heavy mineral data from Peng et al. (2016) and the lack of sediment source change shown here (Fig. 2) do not indicate a source change at the Plio-Pliestocene boundary. This means that 


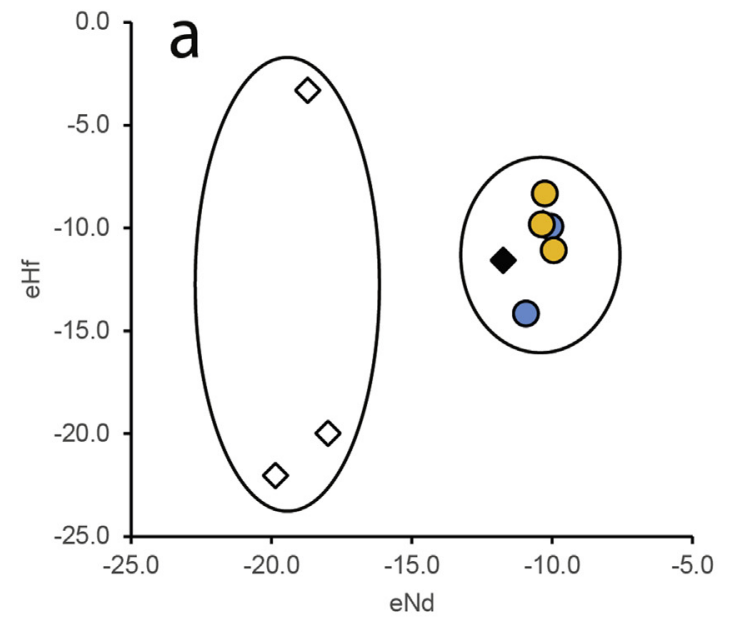

Western Mu Us U-Pb

Eastern Mu Us U-Pb

Yellow River

LGM Loess - Beigouyuan

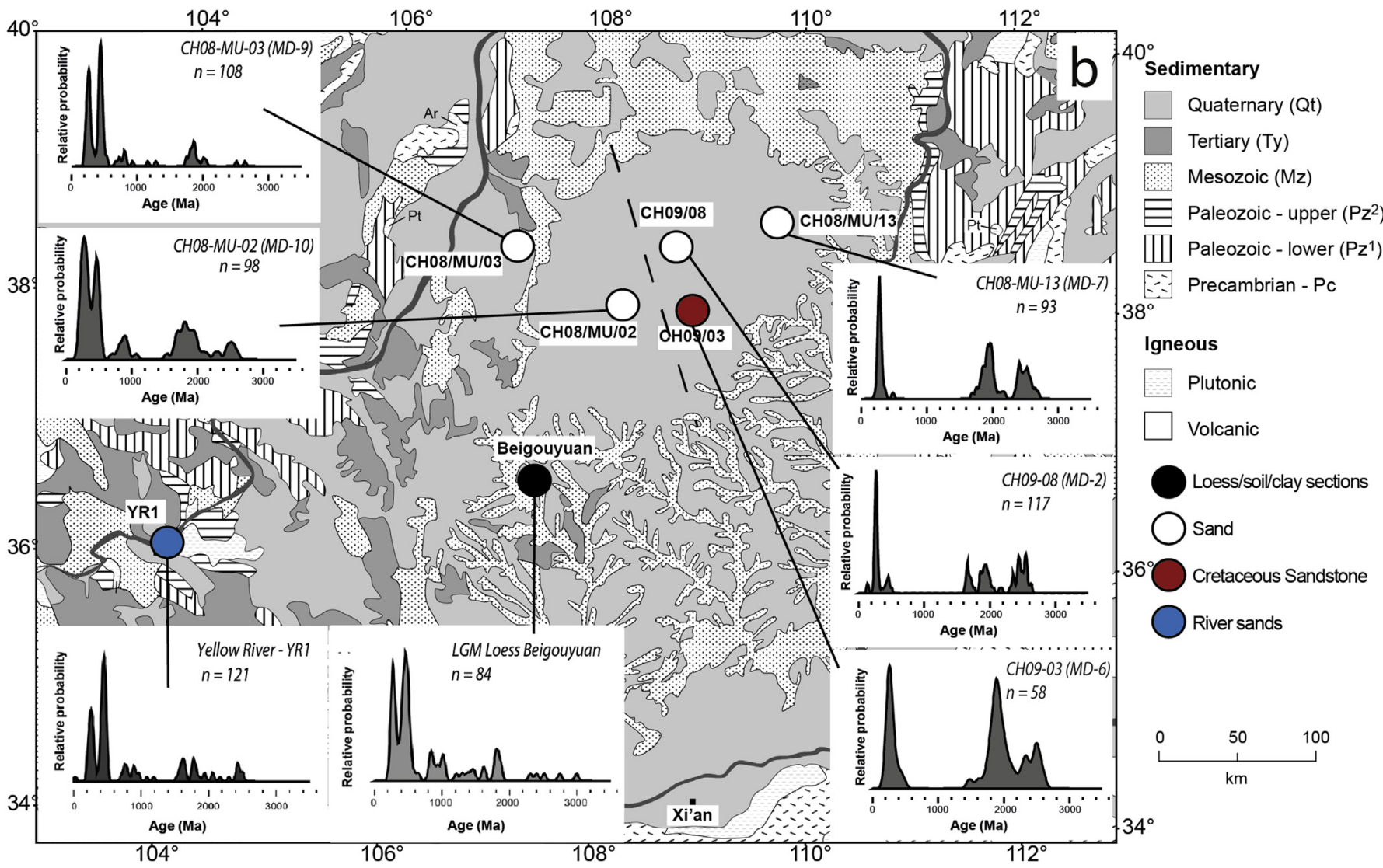

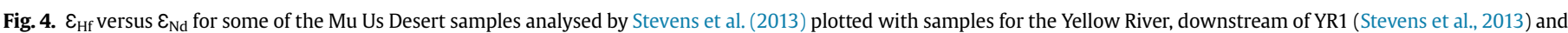

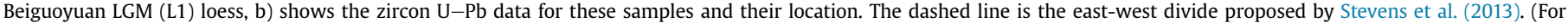
interpretation of the references to colour in this figure legend, the reader is referred to the Web version of this article.)

either that the East Asian winter monsoon must also have been the main transport mechanism for the Red Clay (Peng et al., 2016), or that the westerlies transported material in the Pliocene from the same source, or a source with indistinguishable characteristics, such as that blown in by winter monsoon winds. This would be compatible with the evidence for a dominant NTP source for much of the CLP dust material (Fig. 5). An alternative explanation is that because the fine-grained fraction dominates the isotope signal, the source of this fine fraction could remain the same in loess, soil and Red Clay. By contrast, the coarse fraction may still vary due to abrupt climate shifts and changes in large dust storm tracks. This focus on different grain sizes with different provenance techniques might also explain why there is no clear variation in course $(>10 \mu \mathrm{m})$ detrital zircon $\mathrm{U}-\mathrm{Pb}$ age between loess and palaeosol layers (Pullen et al., 2011), although this should be seen in the Hf$\mathrm{Nd}-\mathrm{Sr}$ data. If this was the case, we might expect to see variation in Hf concentration between the Red Clay and loess relating to the proportion of zircons in the coarse fraction. However, this change is not apparent in the sample set here. In addition to this, recent grain size and zircon $\mathrm{U}-\mathrm{Pb}$ work suggest that there is a SW to NE source variation within the Red Clay (Shang et al., 2016), which suggests that perhaps the East Asian Winter Monsoon played an important 


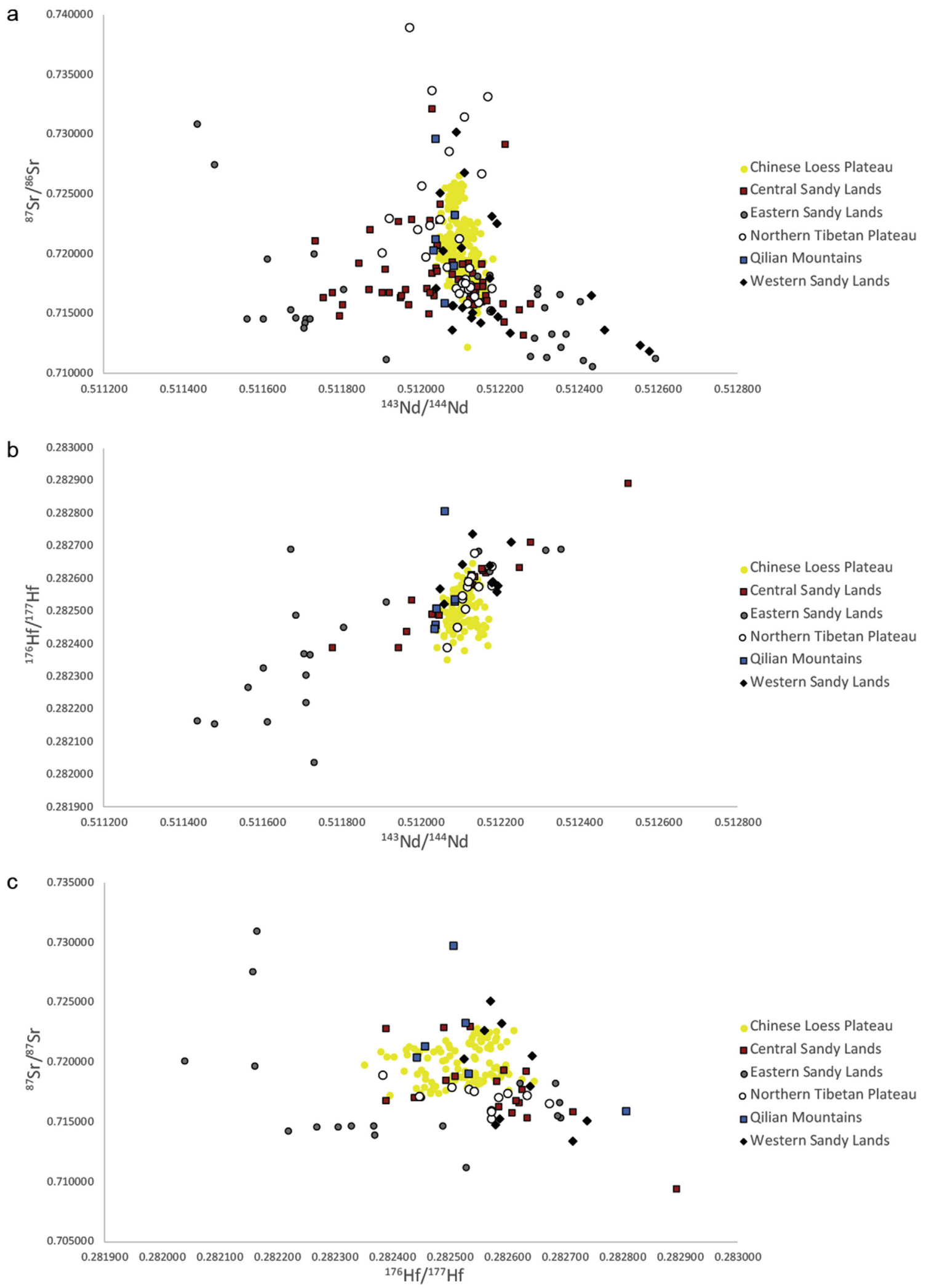

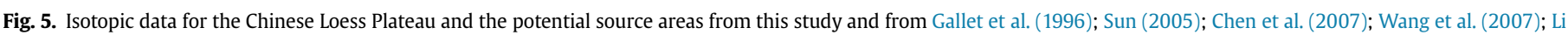

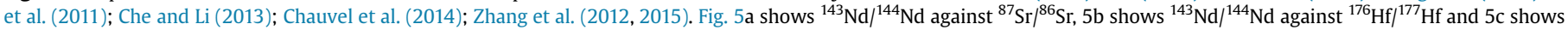
${ }^{176} \mathrm{Hf} /{ }^{177} \mathrm{Hf}$ against ${ }^{87} \mathrm{Sr} /{ }^{86} \mathrm{Sr}$. 
role in the deposition of the Red Clay as well as the Quaternary loess (Liu, 1985; An et al., 1990; Lu et al., 2001).

Our results support assertions that the NTP is the major dust source to the CLP over the whole Plio-Quaternary. As such, climate changes driving dust production efficiency in this region are likely the main control on shifts in the dust cycle over this interval, rather than the addition of new sources by a progressive aridification over an increasing geographical area.

\section{Conclusions}

The data here show that there is no source change in dust supply to the Chinese Loess Plateau at 1.2 Ma or at 2.5 Ma. Changes seen in ${ }^{87} \mathrm{Sr} /{ }^{86} \mathrm{Sr}$ are recording grain-size and/or chemical weathering effects. The change from Red Clay to loess is likely driven by decreased humidity and increased dust deposition across the Pliocene/Quaternary transition. This study has clear implications for understanding the effects of weathering on $\mathrm{Sr}$ isotopes and the importance of using different provenance tools in conjunction to fully understand sediment source.

The isotope data shows that dust sources for the Chinese Loess Plateau are dominated by material from the Northern Tibetan Plateau. This lack of source change across the Pliocene-Pleistocene boundary suggests that the East Asian Monsoon played an important role in the deposition of the Red Clay as well as in the Quaternary loess and that the main dust transporting winds have not drastically changed trajectory since the Miocene, even if the volume of material has increased dramatically.

\section{Author contribution statement}

$A B, T S, M R$ and HL collected the samples. AB, IM and TR undertook all of the laboratory work. AB, TS, IL, PV and HL contributed to data analysis and manuscript production.

\section{Declaration of competing interest}

The authors declare no competing financial interests.

\section{Acknowledgements}

We thank Zhiwei Xu, Hanzhi Zhang, Lin Zeng, Han Feng for help in sampling. This research is partly granted by NERC Standard Grant (NE/I008837/1) and National Natural Science Foundation of China grants (41690111, 41472138). We wish to thank Alex Pullen and an anonymous reviewer for constructive reviews which helped to improve this manuscript.

\section{Appendix A. Supplementary data}

Supplementary data to this article can be found online at https://doi.org/10.1016/j.quascirev.2019.106042.

\section{References}

An, Z.S., Liu, T.S., Lou, Y.C., Porter, S.C., Kukla, G., Wu, X.H., Hua, Y.M., 1990. The longterm paleomonsoon variation recorded by the loess-palaeosol sequence in central China. Quat. Int. 7-8, 91-95.

Bird, A., Stevens, T., Rittner, M., Vermeesch, P., Carter, A., Andò, S., Garzanti, E., Lu, H. Nie, J., Zeng, L., Zhang, H., Xu, Z., 2015. Quaternary dust source variation across the Chinese Loess Plateau. Palaeogeogr. Palaeoclimatol. Palaeoecol. 435, 254-264. https://doi.org/10.1016/j.palaeo.2015.06.024.

Blum, J.D., Erel, Y., 1997. Rb-Sr isotope systematics of a granitic soil chronosequence: The importance of biotite weathering, 61, 3193-3204.

Blum, J.D., Erel, Y., Brown, K., 1993. 87Sr/86Sr ratios of sierra Nevada stream waters: implications for relative mineral weathering rates. Geochem. Cosmochim. Acta 57, 5019-5025. https://doi.org/10.1016/S0016-7037(05)80014-6.

Bouvier, A., Vervoort, J.D., Patchett, P.J., 2008. The Lu-Hf and Sm-Nd isotopic composition of CHUR: constraints from unequilibrated chondrites and implications for the bulk composition of terrestrial planets. Earth Planet. Sci. Lett. 273, 48-57. https://doi.org/10.1016/j.epsl.2008.06.010.

Chauvel, C., Garçon, M., Bureau, S., Besnault, A., Jahn, B.M., Ding, Z., 2014. Constraints from loess on the Hf-Nd isotopic composition of the upper continental crust. Earth Planet. Sci. Lett. 388, 48-58. https://doi.org/10.1016 j.epsl.2013.11.045.

Che, X., Li, G., 2013. Binary sources of loess on the Chinese Loess Plateau revealed by $\mathrm{U}-\mathrm{Pb}$ ages of zircon. Quat. Res. 80, 545-551. https://doi.org/10.1016/ j.yqres.2013.05.007.

Chen, J., Chen, Y., Liu, L., Ji, J., Balsam, W., Sun, Y., Lu, H., 2006. Zr/Rb ratio in the Chinese loess sequences and its implication for changes in the East Asian winter monsoon strength. Geochem. Cosmochim. Acta 70, 1471-1482. https://doi.org 10.1016/j.gca.2005.11.029.

Chen, J., Li, G., Yang, J., Rao, W., Lu, H., Balsam, W., Sun, Y., Ji, J., 2007. Nd and Sr isotopic characteristics of Chinese deserts: implications for the provenances of Asian dust. Geochem. Cosmochim. Acta 71, 3904-3914. https://doi.org/10.1016/ j.gca.2007.04.033.

Chen, Z., Li, G., 2013. Evolving sources of eolian detritus on the Chinese Loess Plateau since early Miocene: tectonic and climatic controls. Earth Planet. Sci. Lett. 371-372, 220-225. https://doi.org/10.1016/j.epsl.2013.03.044.

Ding, Z., Sun, J., Liu, T., Zhu, R., Yang, S., Guo, B., 1998. Wind-blown origin of the Pliocene red clay formation in the central Loess Plateau, China. Earth Planet. Sci. Lett. 161, 135-143. https://doi.org/10.1016/S0012-821X(98)00145-9.

Ding, Z., Derbyshire, E., Yang, S.L., Yu, Z.W., Xiong, S.F., Liu, T.S., 2002. Stacked 2.6-Ma grain size record from the Chinese loess based on five sections and correlation with the deep-sea $\delta 180$ record. Paleoceanography 17, 1033. https://doi.org/ $10.1029 / 2001$ pa000725.

Ding, Z.L., Rutter, N.W., Sun, J.M., Yang, S.L., Liu, T.S., 2000. Re-arrangement of atmospheric circulation at about 2.6 Ma over northern China: evidence from grain size records of loess-palaeosol and red clay sequences. Quat. Sci. Rev. 19 547-558. https://doi.org/10.1016/S0277-3791(99)00017-7.

Ding, Z.L.Ł., Xiong, S.F., Sun, J.M., Yang, S.L., Gu, Z.Y., Liu, T.S., 1999. Pedostratigraphy and paleomagnetism of a $3 / 4$ 7. 0 Ma eolian loess - red clay sequence at Lingtai, Loess Plateau, north-central China and the implications for paleomonsoon evolution, 152, 49-66.

Erel, Y., Blum, J.D., Roueff, E., Ganor, J., 2004. Lead and strontium isotopes as monitors of experimental granitoid mineral dissolution. Geochem. Cosmochim. Acta 68, 4649-4663. https://doi.org/10.1016/j.gca.2004.04.022.

Faure, G., 2001. Origin of Igneous Rocks. https://doi.org/10.1007/978-3-662-044742.

Gallet, S., Jahn, B., Torii, M., 1996. CHEMICAL Geochemical Characterization of the Luochuan Loess-Paleosol Sequence, China, and Paleoclimatic Implications 2541.

Guo, Z.T., Ruddiman, W.F., Hao, Q.Z., Wu, H.B., Qiao, Y.S., 2002. Onset of Asian Deserti $($ Cation by 22 Myr Ago Inferred from Loess Deposits in China, pp. 159-163.

Gylesjö, S., Arnold, E., 2006. Clay mineralogy of a red clay-loess sequence from Lingtai, the Chinese Loess Plateau. Glob. Planet. Chang. 51, 181-194. https:// doi.org/10.1016/j.gloplacha.2006.03.002.

Han, J., Chen, H., Fyfe, W.S., Guo, Z., Wang, D., Liu, T.S., 2007. Spatial and temporal patterns of grain size and chemical weathering of the Chinese Red Clay Formation and implications for East Asian monsoon evolution. Geochem. Cosmochim. Acta 71, 3990-4004. https://doi.org/10.1016/j.gca.2007.05.027.

Heslop, D., Langereis, C.G., Dekkers, M.J., 2000. A new astrominical timescale for the loess deposits of Northern China. Earth Planet. Sci. Lett. 184, 125-139. https:// doi.org/10.1016/S0012-821X(00)00324-1.

Jahn, B., Gallet, S., Han, J., 2001. Geochemistry of the Xining , Xifeng and Jixian Sections, Loess Plateau of China: Eolian Dust Provenance and Paleosol Evolution during the Last $140 \mathrm{Ka}$.

Jung, S.J.a., Davies, G.R., Ganssen, G.M., Kroon, D., 2004. Stepwise Holocene aridification in NE Africa deduced from dust-borne radiogenic isotope records. Earth Planet. Sci. Lett. 221, 27-37. https://doi.org/10.1016/S0012-821X(04)00095-0.

Kapp, P., Pullen, A., Pelletier, J., Russell, J.L., Goodman, P.J., Cai, F., 2015. From dust to dust: Quaternary wind erosion of the Mu Us Desert and Loess Plateau, China. Geology 43, 835-838. https://doi.org/10.1130/G36724.1.

Li, G., Pettke, T., Chen, J., 2011. Increasing Nd isotopic ratio of Asian dust indicates progressive uplift of the north Tibetan Plateau since the middle Miocene. Geology 39, 199-202. https://doi.org/10.1130/G31734.1.

Licht, A., Pullen, A., Kapp, P., Abell, J., Giesler, N., 2016. Eolian cannibalism: reworked loess and fluvial sediment as the main sources of the Chinese Loess Plateau. Geol. Soc. Am. Bull. 128, 944-956. https://doi.org/10.1130/B31375.1.

Liu, 1985. Loess and the Environment. China Ocean Press, 1985.

Lu, H., Vandenberghe, J., An, Z., 2001. Aeolian origin and palaeoclimatic implications of the 'Red Clay' (north China) as evidenced by grain-size distribution. J. Quat Sci. 16, 89-97. https://doi.org/10.1002/1099-1417(200101)16:1<89::AIDJQS578>3.0.CO;2-8.

Lu, H., Wang, X., Li, L., 2010. Aeolian sediment evidence that global cooling has driven late Cenozoic stepwise aridification in central Asia. Geol. Soc. Lond. Spec. Publ. 342, 29-44. https://doi.org/10.1144/SP342.4.

Lugmair, G.W., Carlson, R.W., 1978. The Sm-Nd history of KREEP. Proc. Lunar Planet. Sci. Conf. 9, 689-704.

Mcdonough, W.F., Sun, S., 1995. McDonough \& Sun 1995 chrondrite PM Comp.pdf. Chem. Geol. 120, 223-253.

Merkel, U., Rousseau, D., Stuut, J., Winckler, G., Gunten, L. Von, Kiefer, T., 2014. DUST 
22.

Nie, J., 2016. A Comparison of Heavy Mineral Assemblage between the Loess and the Red Clay Sequences on the Chinese Loess Plateau. https://doi.org/10.1016 j.aeolia.2016.02.004.

Nie, J., Peng, W., Möller, A., Song, Y., Stockli, D.F., Stevens, T., Horton, B.K., Liu, S., Bird, A., Oalmann, J., Gong, H., Fang, X., 2014. Provenance of the upper Miocene-Pliocene red clay deposits of the Chinese Loess Plateau. Earth Planet. Sci. Lett. 407, 35-47. https://doi.org/10.1016/j.epsl.2014.09.026.

Nie, J., Stevens, T., Rittner, M., Stockli, D., Garzanti, E., Limonta, M., Bird, A., Andò, S Vermeesch, P., Saylor, J., Lu, H., Breecker, D., Hu, X., Liu, S., Resentini, A Vezzoli, G., Peng, W., Carter, A., Ji, S., Pan, B., 2015. Loess Plateau storage of Northeastern Tibetan plateau-derived Yellow River sediment. Nat. Commun. 6 , 8511. https://doi.org/101038/ncomms9511.

Peng, W., Wang, Z., Song, Y., Pfaff, K., Luo, Z., Nie, J., Chen, W., 2016. A comparison of heavy mineral assemblage between the loess and the Red Clay sequences on the Chinese Loess Plateau. Aeolian Res. 21, 87-91. https://doi.org/10.1016/ j.aeolia.2016.02.004.

Porter, S.C., Hallet, B., Wu, X., An, Z., 2001. Dependence of near-surface magnetic susceptibility on dust accumulation rate and precipitation on the Chinese Loess Plateau. Quat. Res. 55, 271-283. https://doi.org/10.1006/qres.2001.2224.

Pullen, a., Kapp, P., McCallister, a.T., Chang, H., Gehrels, G.E., Garzione, C.N., Heermance, R.V., Ding, L., 2011. Qaidam Basin and northern Tibetan Plateau as dust sources for the Chinese Loess Plateau and paleoclimatic implications. Geology 39, 1031-1034. https://doi.org/10.1130/G32296.1.

Rittner, M., Vermeesch, P., Carter, A., Bird, A., Stevens, T., Garzanti, E., Andò, S., Vezzoli, G., Dutt, R., Xu, Z., Lu, H., 2016. The provenance of Taklamakan desert sand. Earth Planet. Sci. Lett. 437, 127-137. https://doi.org/10.1016/ j.epsl.2015.12.036.

Rudnick, R., Gao, S., 2003. Composition of the continental crust. Treatise Geochem. https://doi.org/10.1016/B0-08-043751-6/03016-4.

Shang, Y., Beets, C.J., Tang, H., Prins, M.A., Lahaye, Y., van Elsas, R., Sukselainen, L., Kaakinen, A., 2016. Variations in the provenance of the late Neogene Red Clay deposits in northern China. Earth Planet. Sci. Lett. 439, 88-100. https://doi.org 10.1016/j.epsl.2016.01.031.

Stevens, T., Carter, a., Watson, T.P., Vermeesch, P., Andò, S., Bird, a.F., Lu, H. Garzanti, E., Cottam, M.a., Sevastjanova, I., 2013. Genetic linkage between the Yellow River, the Mu Us Desert and the Chinese Loess Plateau. Quat. Sci. Rev. 78 355-368. https://doi.org/10.1016/j.quascirev.2012.11.032.

Stevens, T., Lu, H., 2010. Radiometric dating of the late Quaternary summer monsoon on the Loess Plateau, China. Geol. Soc. Lond. Spec. Publ. 342, 87-108. https://doi.org/10.1144/SP342.8.

Sun, D., Su, R., Li, Z., Lu, H., 2011. The ultrafine component in Chinese loess and its variation over the past 7.6 Ma: implications for the history of pedogenesis. Sedimentology 58, 916-935. https://doi.org/10.1111/j.1365-3091.2010.01189.

Stevens, T., Palk, C., Carter, A., Lu, H., Clift, P.D., 2010. Assessing the provenance of loess and desert sediments in northern China using U-Pb dating and morphology of detrital zircons. GSA Bulletin 122, 1331-1344. https://doi.org/ 10.1130/B30102.1.

Sun, J., 2005. Nd and Sr isotopic variations in Chinese eolian deposits during the past 8 Ma: implications for provenance change. Earth Planet. Sci. Lett. 240 454-466. https://doi.org/10.1016/j.epsl.2005.09.019.

Sun, J., Zhu, X., 2010. Temporal variations in $\mathrm{Pb}$ isotopes and trace element concentrations within Chinese eolian deposits during the past 8Ma: implication for provenance change. Earth Planet. Sci. Lett. 290, 438-447. https://doi.org 10.1016/j.epsl.2010.01.001.
Sun, Y., Lu, H., An, Z., 2006. Grain size of loess, palaeosol and Red Clay deposits on the Chinese Loess Plateau: significance for understanding pedogenic alteration and palaeomonsoon evolution. Palaeogeogr. Palaeoclimatol. Palaeoecol. 241, 129-138. https://doi.org/10.1016/j.palaeo.2006.06.018.

Sun, Y., Tada, R., Chen, J., Liu, Q., Toyoda, S., Tani, A., Ji, J., Isozaki, Y., 2008. Tracing the provenance of fine-grained dust deposited on the central Chinese Loess Plateau. Geophys. Res. Lett. 35, 1-5. https://doi.org/10.1029/2007GL031672.

Tanaka, T., Togashi, S., Kamioka, H., Amakawa, H., 2000. JNdi-1: a Neodymium Isotopic Reference in Consistency with LaJolla Neodymium, pp. 279-281.

Wang, Y.-X., Yang, J.-D., Chen, J., Zhang, K.-J., Rao, W.-B., 2007. The Sr and Nd isotopic variations of the Chinese Loess Plateau during the past $7 \mathrm{Ma}$ : implications for the East Asian winter monsoon and source areas of loess. Palaeogeogr. Palaeoclimatol. Palaeoecol. 249, 351-361. https://doi.org/10.1016/ j.palaeo.2007.02.010.

Watson, a J., Bakker, D.C., Ridgwell, a J., Boyd, P.W., Law, C.S., 2000. Effect of iron supply on Southern Ocean CO2 uptake and implications for glacial atmospheric CO2. Nature 407, 730-733. https://doi.org/10.1038/35037561.

Wen, L., 2005. Changes in grain-size and sedimentation rate of the Neogene Red Clay deposits along the Chinese Loess Plateau and implications for the palaeowind system. Sci. China, Ser. A D 48, 1452. https://doi.org/10.1360/ $01 \mathrm{yd} 0558$.

White, A.F., Blum, A.E., Bullen, T.D., Vivit, D.V., Schulz, M., Fitzpatrick, J., 1999. The effect of temperature on experimental and natural chemical weathering rates of granitoid rocks. Geochem. Cosmochim. Acta 63, 3277-3291. https://doi.org/ 10.1016/S0016-7037(99)00250-1.

Xiao, G., Zong, K., Li, G., Hu, Z., Dupont-Nivet, G., Peng, S., Zhang, K., 2012. Spatial and glacial-interglacial variations in provenance of the Chinese Loess Plateau. Geophys. Res. Lett. 39 https://doi.org/10.1029/2012GL053304 n/a-n/a.

Xu, Y., Yue, L., Li, J., Sun, L., Sun, B., Zhang, J., Ma, J., Wang, J., 2009. An 11-Ma-old red clay sequence on the Eastern Chinese Loess Plateau. Palaeogeogr. Palaeoclimatol. Palaeoecol. 284, 383-391. https://doi.org/10.1016/ j.palaeo.2009.10.023.

Yang, S., Ding, Z., 2010. Drastic climatic shift at $\sim 2.8 \mathrm{Ma}$ as recorded in eolian deposits of China and its implications for redefining the Pliocene-Pleistocene boundary. Quat. Int. 219, 37-44. https://doi.org/10.1016/j.quaint.2009.10.029.

Zhang, H., Lu, H., Jiang, S.-Y., Vandenberghe, J., Wang, S., Cosgrove, R., 2012. Provenance of loess deposits in the Eastern Qinling Mountains (central China) and their implications for the paleoenvironment. Quat. Sci. Rev. 43, 94-102. https:// doi.org/10.1016/j.quascirev.2012.04.010.

Zhang, H., Lu, H., Stevens, T., Feng, H., Fu, Y., Geng, J., Wang, H., 2018. Expansion of dust provenance and aridification of Asia since $\sim 7.2$ Ma revealed by detrital zircon U-Pb dating. Geophys. Res. Lett. 45, 13437-13448. https://doi.org/ 10.1029/2018GL079888.

Zhang, H., Lu, H., Xu, X., Liu, X., Yang, T., Stevens, T., Bird, A., Xu, Z., Zhang, T., Lei, F., Feng, H., 2016. Quantitative estimation of the contribution of dust sources to Chinese loess using detrital zircon U-Pb age patterns. J. Geophys. Res. Earth Surf. 121, 2085-2099. https://doi.org/10.1002/2016JF003936.

Zhang, W., Chen, J., Li, G., 2015. Shifting material source of Chinese loess since $\sim 2.7$ Ma reflected by $\mathrm{Sr}$ isotopic composition. Sci. Rep. 5, 10235. https://doi.org/ $10.1038 /$ srep 10235.

Zhu, Y., Zhou, L., Mo, D., Kaakinen, A., Zhang, Z., Fortelius, M., 2008. A new magnetostratigraphic framework for late Neogene Hipparion red clay in the eastern Loess Plateau of China. Palaeogeogr. Palaeoclimatol. Palaeoecol. 268, 47-57. https://doi.org/10.1016/j.palaeo.2008.08.001. 